\title{
Effect of Different Manurial Practices on Soil Microbial Activity under SRI Method of Rice Planting
}

\author{
Sowmya Pogula* and K.K. Rout \\ Department of Soil Science \& Agricultural Chemistry, Orissa University of Agricultural \\ Chemistry, Bhubaneswar-751003, India \\ *Corresponding author
}

\section{A B S T R A C T}

\section{Keywords \\ Soil microbial activity, Rice planting \\ Article Info \\ Accepted: \\ 26 March 2018 \\ Available Online: \\ 10 April 2018}

The field experiment was conducted during kharif and rabi season of 2106 to study the effect of different manurial practices on soil microbial activity under SRI method of rice planting. The field experiment was laid out in Randomized block design with 8 treatments replicated thrice. The treatments include incorporation of $100 \% \mathrm{RD}\left(80: 40: 40 \mathrm{~N}: \mathrm{P}_{2} \mathrm{O}_{5}: \mathrm{K}_{2} \mathrm{O}\right.$ $\mathrm{Kg} / \mathrm{ha}$ ) with $10 \mathrm{tFYM} / \mathrm{ha}$ in $\mathrm{T}_{1}, 100 \% \mathrm{RD}$ with $5 \mathrm{tFYM} /$ ha, green manure and biofertilizer in $\mathrm{T}_{2}, 75 \%$ RDF with Nimin + FYM 10t /ha in T3, 75\% RDF with Nimin + FYM 5t/ha + Green Manuring + Biofertilizer inT4, STBR (soil test based fertilizer recommendation) with 10tFYM/ha in T5, STBR with 5tFYM/ha, green manure and biofertilizer in $\mathrm{T}_{6}$, $100 \% \mathrm{RD}$ in $\mathrm{T}_{7}$ and $100 \%$ organic in $\mathrm{T}_{8}$. The results revealed that treatment treated with STBR with $5 \mathrm{tFYM} /$ ha, green manure and biofertilizer showed best result in microbial respiration, microbial population and enzyme activity.

\section{Introduction}

Rice is the principal staple food for $65 \%$ of the population of India. The demand for rice is expected to rise due to increase in population (1.6\% year-1), while the area under rice cultivation is expected to reduce to 40 million ha in the next 15-20 years (Shobarani et al., 2010). Hence, there is a need to increase the yield and productivity of rice cultivation using reduced inputs and resources to feed the burgeoning population. System of rice intensification (popularly known as SRI), an alternative methodology for traditional flooded rice cultivation developed in the 1980s in Madagascar (Laulanie', 1993), offers some instructive insights into "positive plant microbial interactions." SRI has been promoted for more than a decade as a set of agronomic management practices for rice cultivation that enhances yield (Kabir and Uphoff, 2007; Namara et al., 2008; Senthilkumar et al., 2008) while reducing water requirements (Satyanarayana et al., 2007).

The agronomic changes in SRI rice cultivation include the use of much younger seedlings than are normally transplanted, planting them singly and carefully in a square pattern with wide spacing in soil that is kept moist, but not continuously flooded and with increased amendments of organic matter and active aeration of the soil during weed control 
operation preferably with a mechanical weeder. SRI was also found more accessible to small land holders (Stoop et al., 2002) and is more favorable for the environment than conventional transplanting with its continuous flooding and heavy reliance on inorganic fertilization (Uphoff, 2003).

The information on effect of different type manures on soil microbial activity under SRI cultivation is limited. So, the present experiment was conducted on effect of different manorial practices on soil microbial activity under SRI method of rice planting.

\section{Materials and Methods}

SRI cultivation rice plants are transplanted singly and with wide spacing in a square pattern, radically reducing plant population. This practice which differs from usual practice which assume more plants will give more yield, gives the plants root system more room to grow (Thakur et al., 2010). Soil fertility being enhanced by the combination of plantsoil- water- nutrient- microbial interactions supported by SRI practices, making otherwise unavailable nutrient available through microbiological process (Uphoffs, 2003). Hence it is ideally suitable for resource poor farmers.

The field experiment was conducted during kharif and rabi season of 2106 to study the effect of different manurial practices on rice yield and soil biological properties under SRI method of rice planting. The field experiment was laid out in Randomized block design with 8 treatments replicated thrice. The treatments include incorporation of $100 \% \mathrm{RD}(80: 40: 40$ $\mathrm{N}: \mathrm{P}_{2} \mathrm{O}_{5}: \mathrm{K}_{2} \mathrm{O} \mathrm{Kg} / \mathrm{ha}$ ) with $10 \mathrm{t} \mathrm{FYM} / \mathrm{ha}$ in $\mathrm{T}_{1}$, $100 \%$ RD with $5 \mathrm{tFYM} / \mathrm{ha}$, green manure and biofertilizer in $\mathrm{T}_{2}, 75 \% \mathrm{RDF}$ with Nimin + FYM 10t /ha in T3, 75\% RDF with Nimin + FYM 5t/ha + Green Manuring + Biofertilizer inT4, STBR(soil test based fertilizer recommendation) with $10 \mathrm{tFYM} / \mathrm{ha}$ in $\mathrm{T} 5$, STBR with $5 \mathrm{tFYM} / \mathrm{ha}$, green manure and biofertilizer in $\mathrm{T}_{6}, 100 \% \mathrm{RD}$ in $\mathrm{T}_{7}$ and $100 \%$ organic in $\mathrm{T}_{8}$

The pooled sample was transferred into polythene bags, stored in an ice-cold thermocol box and transported to the laboratory. These bags were stored in a refrigerator at $4 \mathrm{C}$ until analyzed for two soil biological activity indicators, dehydrogenase, urease, phosphatase and microbial respiration as per the protocols of Casida (1977) and Anderson and Domsch (1989), respectively, and for three microbiological variables (populations of total bacteria, actinomycetes, and fungi). Appropriate dilutions of the soil samples were plated on Luria agar for bacteria, actinomycetes isolation agar for actinomycetes and potato dextrose agar (PDA) with streptomycin @ 500 mg L-1 for fungi. The plates were incubated at $30 \pm 2 \mathrm{C}$ for 24 $120 \mathrm{~h}$. The colonies with desired traits on different media were counted and recorded. The data were transformed into log units and expressed as colony forming units (CFU) $\log 10 \mathrm{~g}-1$ dry soil. Moisture in the different soil samples was determined and the counts were converted to gram-1 dry soil.

\section{Results and Discussion}

\section{Microbial population}

As we know the microbes play important in soil fertility and also in crop production. So it is important to focus on the microbial population. The microbes help in increase of the availability of nutrients to the plant. In this study the microbial population like bacteria, fungi and actinomycetes count was calculated to know the number. In SRI cultivation as the paddy seedlings were transplanted widely and there is no submergence of paddy crop as in conventional method. The paddy crop is cultivated with less water and so there is more 
aeration in soil. Due to the wide spacing the roots of the crop grows well and due to more aeration in soil the microbial population is more as compared to the conventional method. In this experiment we had studied the effect of different manures on microbial population.

The results showed that the (Table 1) bacteria, fungi and actinomycetes population was highest in the treatment treated with STBR with 5tFYM/ha, green manure and biofertilizer and which was followed by the treatment treated with $100 \% \mathrm{RD}$ with $5 \mathrm{tFYM}$ /ha, green manure and biofertilizer in both kharif and rabi season.

\section{Microbial respiration}

Soil microbial respiration, i.e. the production of carbon dioxide (CO2) through soil organic carbon (C) decomposition by microbes, is an important component of the global $\mathrm{C}$ cycle (Schlesinger and Andrews 2000; Kaštovská et al., 2010). Soil microbial respiration is controlled by soil carbon pools (e.g., microbial $\mathrm{C}$, labile and resistant $\mathrm{C}$ ) and environmental conditions, but the contribution of different components of soil organic carbon is not well understood.

There is no clear reported relationship between soil microbial respiration and carbon pools though a first order relationship is commonly used in many soil models to estimate the influence of changing soil carbon components on microbial respiration (Parton et al., 1987; Li et al., 1993; Coleman and Jenkinson, 1996). The rate of change in TOC pool is normally slow, and the decomposition of resistant carbon is less responsible for the variation in soil respiration (Whalen et al., 2000). Labile carbon pools, such as soil microbial carbon (Cmic), have been suggested as more sensitive indices of long-term trends in soil organic matter (Sparling et al., 1998; Islam et al., 2000).
Microbial respiration index of the microbial activity in soil is measured by the measurement of carbon dioxide evolution.

The results revealed that the microbial respiration was highest in the treatment treated (Table 2) with STBR with 5tFYM/ha, green manure and biofertilizer and which was followed by the treatment treated with $100 \%$ RD with 5 tFYM /ha, green manure and biofertilizer in both kharif and rabi season. This indicates that due to increase in organic matter the microbial decomposition increases and the evolution of carbon dioxide increase which indicate the microbial respiration.

\section{Enzyme activity}

Soil enzyme activity depends on optimal soil moisture and aeration, organic carbon and nitrogen content. Among the soil enzyme urease, dehydrogenase and phosphotase activity also depends on soil type, physicochemical properties, plant species being grown, and their development stage. Enzyme activity is particular high in the rhizosphere where the release of root exudase sustains higher microbial biomass and activity than in bulk soil.

Microorganisms produce a variety of enzymes in soil. The types of enzymes produced vary with the environment conditions. Some bacteria or fungi produce substrate-specific enzyme like cellulose, phenolase, esterase etc. only when a particular substrate is present.

Some enzymes such as dehydrogenase, urease etc. are always present in cells and are produced without the influence of any substrate.

Soil enzyme activities and microbial number have good correlation. 
Table.1 Effect of different manurial practices on soil microbial population in both kharif and rabi season

\begin{tabular}{|c|c|c|c|c|c|c|c|}
\hline & Treatements Details & $\begin{array}{l}\text { Total } \\
\text { bacteria } \\
\text { (log10 g-1 } \\
\text { dry soil)in } \\
\text { Kharif }\end{array}$ & $\begin{array}{l}\text { Total } \\
\text { bacteria(lo } \\
\text { g10 g-1 } \\
\text { dry soil) in } \\
\text { Rabi }\end{array}$ & $\begin{array}{l}\text { Total } \\
\text { fungi } \\
\text { (log10 g-1 } \\
\text { dry soil) in } \\
\text { Kharif }\end{array}$ & $\begin{array}{l}\text { Total } \\
\text { fungi(log10 } \\
\text { g-1 dry soil) } \\
\text { in Rabi }\end{array}$ & $\begin{array}{l}\text { Total actinomycetes } \\
(\log 10 \mathrm{~g}-1 \text { dry soil) in } \\
\text { kharif }\end{array}$ & $\begin{array}{l}\text { Total } \\
\text { actinomycetes } \\
\text { (log10 g-1 dry } \\
\text { soil)in Rabi }\end{array}$ \\
\hline T1 & $100 \%$ RDF + FYM 10t /ha & 3.2 & 4.1 & 3.14 & 4.22 & 4.22 & 4.53 \\
\hline $\mathbf{T 2}$ & $\begin{array}{l}100 \% \text { RDF + FYM 5t/ha +Green } \\
\text { Manuring + Biofertilizer }\end{array}$ & 4.23 & 4.34 & 4.21 & 4.53 & 4.32 & 4.21 \\
\hline T3 & $75 \%$ RDF with Nimin + FYM 10t /ha & 3.19 & 3.54 & 3.45 & 4.13 & 3.22 & 3.55 \\
\hline T4 & $\begin{array}{l}\text { 75\% RDF with Nimin + FYM 5t/ha + } \\
\text { Green Manuring + Biofertilizer }\end{array}$ & 2.11 & 3.15 & 3.55 & 4.22 & 3.2 & 3.56 \\
\hline T5 & STBR + FYM 10t /ha & 4.37 & 4.34 & 3.25 & 4.22 & 4.56 & 4.67 \\
\hline T6 & $\begin{array}{l}\text { STBR+ FYM 5t /ha + Green Manuring } \\
+ \text { Biofertilizer }\end{array}$ & 5.23 & 5.45 & 6.34 & 6.56 & 5.34 & 5.55 \\
\hline T7 & $100 \% \mathrm{RDF}$ & 3.12 & 3.54 & 4.23 & 4.34 & 3.16 & 3.67 \\
\hline T8 & $\begin{array}{l}100 \% \text { Organic (Green manuring + } \\
\text { FYM + Mataka khata+ Biofertilizer) }\end{array}$ & 4.03 & 4.23 & 4.56 & 5.22 & 3.12 & 4.33 \\
\hline
\end{tabular}

Table.2 Effect of different manurial practices on soil microbial respiration in both kharif and rabi season

\begin{tabular}{|c|c|c|c|}
\hline $\begin{array}{l}\text { Sl. } \\
\text { No. }\end{array}$ & Treatments & $\begin{array}{l}\text { Microbial Respiration (mg } \\
\mathrm{CO}_{2} \text { /gm soil/24hours) in Kharif }\end{array}$ & $\begin{array}{l}\text { Microbial Respiration(mg } \\
\mathrm{CO}_{2} \text { /gm soil/24hours) in Rabi }\end{array}$ \\
\hline $\mathbf{T}_{1}$ & $100 \%$ RDF + FYM 10t /ha & 23.32 & 24.833 \\
\hline T2 & $100 \%$ RDF + FYM 5t/ha +Green Manuring + Biofertilizer & 25.51 & 26.667 \\
\hline $\mathbf{T}_{3}$ & $75 \%$ RDF with Nimin + FYM 10t /ha & 23.25 & 25.467 \\
\hline $\mathbf{T}_{4}$ & $\begin{array}{l}\text { 75\% RDF with Nimin + FYM 5t/ha + Green Manuring + } \\
\text { Biofertilizer }\end{array}$ & 24.05 & 26.233 \\
\hline $\mathbf{T}_{5}$ & STBR + FYM 10t /ha & 25.38 & 23.200 \\
\hline $\mathrm{T}_{6}$ & STBR+ FYM 5t /ha + Green Manuring + Biofertilizer & 27.26 & 28.567 \\
\hline $\mathbf{T}_{7}$ & $100 \% \mathrm{RDF}$ & 23.35 & 24.000 \\
\hline $\mathbf{T}_{\mathbf{8}}$ & $\begin{array}{l}\text { 100\% Organic (Green manuring + FYM + Mataka khata+ } \\
\text { Biofertilizer) }\end{array}$ & 23.15 & 19.467 \\
\hline & CD (0.05) & 4.108(NS) & (NS) \\
\hline & $\mathrm{CV}(\%)$ & 9.71 & 18.0 \\
\hline
\end{tabular}


Table.3 Effect of different manurial practices on enzyme activity in both kharif and rabi season

\begin{tabular}{|c|c|c|c|c|c|c|c|}
\hline $\begin{array}{l}\text { Sl. } \\
\text { No. }\end{array}$ & Treatments & $\begin{array}{c}\text { Dehydrogenase( } \mu \mathrm{g} \\
\text { of TPF/gm } \\
\text { soil/24hours) in } \\
\text { Kharif }\end{array}$ & $\begin{array}{c}\text { Dehydrogenase( } \mu \mathrm{g} \\
\text { of TPF/gm } \\
\text { soil/24hours)in } \\
\text { Rabi }\end{array}$ & $\begin{array}{l}\text { Urease(mg } \\
\mathrm{NH}_{4}{ }^{+} / \mathrm{kg} \\
\text { soil/24 hours) } \\
\text { in Kharif }\end{array}$ & $\begin{array}{l}\text { Urease(mg } \\
\mathrm{NH}_{4}^{+} / \mathrm{kg} \\
\text { soil/24 } \\
\text { hours)in Rabi }\end{array}$ & $\begin{array}{l}\text { Phosphatase } \\
\text { (mg PNP/ kg } \\
\text { soil/1hour)In } \\
\text { Kharif }\end{array}$ & $\begin{array}{l}\text { Phosphatase } \\
\text { (mg PNP/ kg } \\
\text { soil/1hour)in } \\
\text { Rabi }\end{array}$ \\
\hline $\mathbf{T}_{1}$ & $100 \%$ RDF + FYM 10t /ha & 150 & 71.680 & 49.93 & 28.52 & 272 & 109.57 \\
\hline $\mathrm{T} 2$ & $\begin{array}{l}100 \% \text { RDF + FYM 5t/ha +Green } \\
\text { Manuring + Biofertilizer }\end{array}$ & 175 & 124.887 & 51.67 & 29.21 & 337 & 125.80 \\
\hline$\overline{T_{3}}$ & $\begin{array}{l}\text { 75\% RDF with Nimin + FYM 10t } \\
\text { /ha }\end{array}$ & 141 & 73.823 & 43.73 & 28.81 & 250 & 122.07 \\
\hline $\mathbf{T}_{4}$ & $\begin{array}{l}\text { 75\% RDF with Nimin + FYM 5t/ha } \\
+ \text { Green Manuring + Biofertilizer }\end{array}$ & 186 & 120.237 & 50.45 & 26.17 & 322 & 122.23 \\
\hline $\mathbf{T}_{5}$ & STBR + FYM 10t /ha & 192 & 95.797 & 50.37 & 28.96 & 334 & 120.50 \\
\hline $\mathbf{T}_{7}$ & $100 \% \mathrm{RDF}$ & 132 & 98.683 & 49.60 & 26.18 & 268 & 122.47 \\
\hline $\mathbf{T}_{8}$ & $\begin{array}{l}\text { 100\% Organic (Green manuring + } \\
\text { FYM + Mataka khata+ } \\
\text { Biofertilizer) }\end{array}$ & 144 & 114.327 & 47.73 & 28.80 & 268 & 115.10 \\
\hline & $\mathrm{CD}(0.05)$ & $51.916(\mathrm{~S})$ & $36.27(\mathrm{~S})$ & $2.872(\mathrm{~S})$ & $14.48(\mathrm{~S})$ & $35.885(\mathrm{~S})$ & $25.5(\mathrm{~S})$ \\
\hline & $\mathrm{CV}(\%)$ & 18.13 & 19.80 & 3.33 & 27.34 & 6.84 & 12.24 \\
\hline
\end{tabular}


Dehydrogenase is an enzyme that occurs in all viable microbial cells. These enzymes function as a measurement of the metabolic state of soil microorganisms (Watts et al., 2010). Dehydrogenase activity (DHA) is one of the most adequate, important and one of the most sensitive bioindicators, relating to soil fertility (Wolinska and Stepniewska, 2012). Its activity depends from the same factors, which influence on microorganisms abundance and activity. Besides, it is well known that pesticides have inhibiting effects on DHA (Karaca et al., 2011; Wolinska and Stepniewska, 2012)

Those enzymes that hydrolyse $\mathrm{P}$ esters are commonly called phosphatases. Soil phosphatases then play a major role in the mineralization processes (dephosphorylation) of organic $\mathrm{P}$ substrates. Appiah and Thompson (1974) proposed that the mineralization of organic phosphorus is principally a microbial phenomenon and they suggest further that phosphatase activity becomes important after the initial breakdown of soil organic matter once catalysed by a host of microbial enzymes.

The initial breakdown could be the rate limiting step of organic phosphorus mineralization. The organic phosphorus mineralization in soil correlated with the nitrogen and carbon mineralized (Thompson et al., 1954). Ridge and Rovira (1971) describe the important role of root surface enzymes in phosphorus mineralization compared to the larger amounts of enzymes more distant from the roots and bound to clay and organic matter. Some results indicate a more important role might be played by microbial phosphatase than cell-free phosphatase. However, under conditions in soils cell-free phosphatase constitutes the major proportion of these enzymes and should play a considerable role in the constant mineralization of organic matter (Speir, Ross
1978). Hoffmann (1968) suggested three types of phosphatases - acid, neutral and alkaline (different $\mathrm{pH}$ optima).

The results revealed that the activity of dehyderogenase, urease and phosphatase was highest in the treatment treated (Table 3) with STBR with 5tFYM/ha, green manure and biofertilizer and which was followed by the treatment treated with $100 \%$ RD with $5 \mathrm{tFYM}$ /ha, green manure and biofertilizer in both kharif and rabi season. This indicates that due to increase in the organic matter the microbial population was more and also enzyme activity also more

The present investigation has concluded that incorporation of soil test based fertilizer recommendation along with $5 \mathrm{tFYM} / \mathrm{ha}$, green manure and biofertilizer had showed best result in microbial population, microbial respiration and enyme activity under SRI cultivation of rice in both kharif and rabi season. The treatment (T2) treated with $100 \%$ $\mathrm{RD}$ along with $5 \mathrm{tFYM} / \mathrm{ha}$, green manure and biofertilizer also showed on par results as T6 in microbial population, microbial respiration and enyme activity under SRI cultivation of rice.

\section{References}

Kabir H, Uphoff N (2007) Results of disseminating the System of Rice Intensification with Farmer Field School methods in Northern Myanmar. Exp Agric 43:4

Karaca A., Cetin S.C., Turgay O.C., Kizilkaya R. (2011): Soil enzymes as indication of soil quality. In: Shukla G., Varma A. (eds.): Soil Enzymology. Springer-Verlag, Berlin, Heidelberg, 119-148.

Satyanarayana A, Thiyagarajan TM, Uphoff N (2007) Opportunities for water saving 
with higher yield from the system of rice intensification. Irrig Sci 25:99-115

Shobarani N, Prasad GSV, Prasad ASR, Sailaja B, Muthuraman P, Numeera S, Viraktamath BC (2010) Rice AlmanacIndia. DRR Technical Bulletin No 5, Directorate of Rice Research, Rajendranagar, Hyderabad, pp 6-7

Thakur AK, Rath S, Roychowdhury S, Uphoff N (2010) Comparative performance of rice with system of rice intensification (SRI) and conventional management using different plant spacings. J Agron Crop Sci 196:146159

Uphoff N (2003) Higher yields with fewer external inputs? The system of rice intensification and potential contributions to agricultural sustainability. Int J Agric Sustain 1:3850

Wolinska A., Stepniewska Z. (2012): Dehydrogenase activity in the soil environment. In: Canuto R.A. (ed.): Dehydrogenases. Intech.

\section{How to cite this article:}

Sowmya Pogula and Rout, K.K. 2018. Effect of Different Manurial Practices on Soil Microbial Activity under SRI Method of Rice Planting. Int.J.Curr.Microbiol.App.Sci. 7(04): 3221-3227. doi: https://doi.org/10.20546/ijcmas.2018.704.365 